\title{
Penghancuran Estetika Kota: Bangunan Bersejarah di Kota Medan
}

\author{
Oleh \\ Asmyta Surbakti \\ Fakultas Sastra Universitas Sumatera Utara
}

\begin{abstract}
In the last two decades, specially when Medan City has got involved in the urban developmentalism, through the modernization and capital globalization, many historical buildings are destructed in order to build shopping centres, through hegemony and/or demolition by neglection. Using their hegemonic discourses, the local government supports controversially the destruction although the Perda was already issued. The most important discourse is the promise that the shopping centres will create employment for the local people as well as generate revenues for the government. To resist the destruction, counter-hegemonic ones are built by the society supported by critical groups, such as non-governmental organizations called Badan Warisan Sumatra (Sumatra Heritage Trust (BWS/SHT) with the central figure Hasti Tarekat as well as intellectuals, and mass media. Such a destruction does not only omit history and identity of the city but also neglect the tourism development based on the aesthetics of the heritages, which is potential to emansipatory praxis of the society.
\end{abstract}

Keywords: Destruction, aesthetics, built heritage, tourism.

\section{PENDAHULUAN}

Kota Medan sebagai salah satu kota besar di Indonesia berpenduduk sangat heterogen dengan kehidupan multikulturalnya yang sudah dikenal sejak ibukota Provinsi Sumatera Utara ini berdiri pada pertengahan abad ke-16. Pola kehidupan plural sejak pra-Indonesia seperti itu tercermin juga dalam kebudayaan fisik kotanya melalui ratusan bangunan bersejarah tinggalan kolonial yang sangat menarik, yang saat ini dapat disaksikan terutama dalam berbagai fungsi baru seperti rumah tinggal, kantor, hotel, rumah toko, tempat peribadatan, rumah sakit, dan sekolah. Secara estetika, bangunan tersebut pada umumnya merupakan paduan gaya, desain, dan arsitektur Melayu, Belanda, India, Inggris, dan Cina, sebagai akumulasi dan kristalisasi sejarah Kota Medan sendiri, yang dapat ditelusuri sejak era penanaman tembakau Deli di Sumatera Timur pada tahun 1863.

Namun, di tengah semangat upaya pelestarian budaya dan industrialisasi pariwisata, fenomena paradoksal tak terhindarkan terjadi karena, dalam kenyataannya, satu persatu bangunan bersejarah di Kota Medan dirubuhkan dan diganti dengan bangunan modern. 
Perubuhan relatif begitu mudahnya terjadi di tangan pemilik baru bangunan bersejarah, yaitu para pengusaha, yang sangat dekat dengan kekuasaan, sehingga bangunan modern yang menggantikan hampir selalu terkait dengan kepentingan bisnis, seperti supermarket, mall, plaza, dan sebagainya. Tidak mengherankan, meskipun telah dikeluarkan Perda No. 6 Tahun 1988 tentang Perlindungan Bangunan dan Lingkungan yang Bernilai Sejarah di Kota Medan yang mencakup 42 bangunan dan dua kawasan yang harus dilestarikan, penghancuran bangunan bersejarah tetap saja berlangsung. LSM Badan Warisan Sumatera (BWS) melaporkan, di wilayah Pemkot Medan, sudah ada puluhan bangunan tua yang dihancurkan padahal sekitar 400 bangunan lagi belum dimasukkan dalam Perda (detik.com, 26 Oktober 2004).

Dalam catatan Kompas (27 Oktober 2004), sejak adanya Perda tersebut, puluhan bangunan bersejarah yang dihancurkan di antaranya mencakup tempat pengadilan kerajaan Kerapatan Adat Deli, Sekolah Menengah Pertama Negeri 1 Medan (1999) di Jalan Cut Mutia yang kemudian menjelma menjadi tiga pintu rumah tinggal (1989), Mega Eltra (2002) di Jalan Brigjen Katamso, sembilan rumah panggung di Jalan Timur, dan puluhan bangunan bersejarah di Jalan Kesuma. Terakhir, pada tahun 2004, Eks Bank Modern di Jalan Ahmad Yani (dibangun 1929) dihancurkan dan kemudian menjadi lima ruko berlantai 5 dan Kompleks perkantoran Perusahaan Perkebunan Sipef (PT Tolan Tiga) di persimpangan antara Jalan S. Parman dan Jalan Zainul Arifin (dibangun 1920) mengalami nasib yang sama yang akhirnya menjadi Cambridge Condominium.

Dengan itu, Kota Medan nanti diasumsikan akan kehilangan karakter utama dan identitas historisnya yang terkait dengan aesthetics of a city. Dominasi konstruksi peninggalan Belanda yang menjadi ciri bangunan bersejarah hanya akan menjadi cerita dan kenangan yang indah dan tidak akan bisa disaksikan lagi oleh generasi-generasi yang akan datang padahal "bangunan bersejarah sebagai estetika kota itulah Kota Medan!" Sejalan dengan itu, perubuhan bangunan bersejarah bertentangan dengan pelestarian budaya dan upaya industrialisasi pariwisata berbasis bangunan bersejarah yang akhir-akhir ini mulai digalakkan, yang berarti secara sistematis mematikan semangat kewirausahaan sektor-sektor kecil-informal terkait pariwisata dan, sebaliknya, mendukung kapitalisme kota melalui pembangunan supermarket dan sejenisnya yang berskala besar dan hanya menguntungkan pemodalnya secara sepihak tetapi bukan masyarakat kebanyakan. 
Berdasarkan paparan di atas, tugas ini mengambil judul "Penghancuran Estetika Kota: Bangunan Bersejarah di Kota Medan”. Sebagai sebuah kajian budaya (cultural studies), tulisan ini tidak mengabaikan sisi-sisi kontekstual atau apa yang tengah terjadi atau berlangsung (dalam hal ini: penghancuran) di sekitar teks yang dibahas, yaitu estetika kota berupa tampilan bangunan bersejarah di Kota Medan.

\section{SEJARAH BANGUNAN BERSEJARAH}

Keberadaan bangunan bersejarah dalam jumlah yang cukup banyak di Kota Medan yang berkaitan dengan era penanaman tembakau Deli di Sumatera Timur tersebut dipelopori oleh J. Nienhuyis, Van Der Falk, dan Elliot. Keuntungan besar yang diperoleh dari perkebunan ini -pada tahun 1874 sudah dibuka 22 buah perkebunan-- membuat pemerintah kolonial Belanda memindahkan ibukota Residensi Sumatera Timur dari Bengkalis ke Medan pada tanggal 1 Maret 1887 (Sinar, 2001). Pada saat itulah, pembangunan infrastruktur dimulai dan arsitektur Eropa mulai mengisi wajah Kota Medan di mana, dapat dikatakan, pada saat itu sebagian besar Kota Medan terdiri atas rawa-rawa dan transportasi antarkota dilakukan melalui sungai. Arsitektur yang diperkenalkan mulai dari arsitektur klasik sampai arsitektur art deco yang dalam aplikasinya berusaha bersahabat dengan alam tropis.

Sarana pendukung yang dibangun oleh pemerintah kolonial antara lain Kantor Pos Besar Medan yang didirikan pada tahun 1879 dan pada tahun itu pula dibentuk perkumpulan orang Belanda Wittie Societeit. Pada tahun 1881, Deli Mij membuka perusahaan kereta api Deli Spoorweg Maatschappij dan pada tahun 1886 membuka sarana telepon yang pada tahun 1900 sudah memiliki 213 pelanggan. Mengingat kemajuan dagang yang memerlukan perputaran uang, didirikan cabang The Chartered Bank pada tahun 1887 sedangkan gedung-gedung perkapalan di Belawan dibangun pada tahun 1889. Pada tahun 1888 dibangun Medan Hotel yang dahulu dikenal sebagai House of Food, sebuah tempat kesukaan tuan-tuan kebun saat datang ke Medan. Hotel ini juga menjadi pemasok bir dingin ke perkebunan-perkebunan yang ada di seputar Kota Medan. Rumah sakit pertama yang dibangun adalah Eerste School voor Openbare Onderwijs pada tahun 1888. Pada tahun 1898 dibangun sekolah untuk golongan bumi putera bernama Eereste Inlandsche School der 2e Klasse (Sinar, 2001). 
Di kota yang terus berkembang modern dan semakin turistik seperti Kota Medan, banyaknya bangunan bersejarah tertuang secara resmi dalam kawasan-kawasan pariwisata yang dikembangkan. Keseriusan mengembangkan diri menjadi sebuah kota wisata terlihat di antaranya dalam upaya penzonean wilayah kota ke dalam delapan kawasan wisata. Di luar kawasan-kawasan tersebut, masih banyak terdapat bangunan bersejarah tinggalan kolonial di samping yang sudah dihancurkan, yang sampai kini tidak atau belum (di)masuk(kan) kawasan wisata karena dianggap berada di luar jalur pariwisata Kota Medan. Di bawah ini adalah penggambaran seluruh kawasan pariwisata di Kota Medan dan beberapa bangunan bersejarah terpenting yang menjadi bagiannya (lihat tabel).

Tabel Pengembangan Kawasan Wisata Berbasis Bangunan Bersejarah di Kota Medan

\begin{tabular}{|l|l|}
\hline \multicolumn{1}{|c|}{ Kawasan } & \multicolumn{1}{|c|}{ Kawasan Wisata dan Bangunan Bersejarah yang Dicakup } \\
\hline Kawasan I & $\begin{array}{l}\text { Gedung Balai Kota, Gedung Bank Indonesia, Gedung Dharma Deli, } \\
\text { Kantor Pos Besar, Stasiun Kereta Titi Gantung, dan Taman } \\
\text { Merdeka. }\end{array}$ \\
\hline Kawasan II & $\begin{array}{l}\text { Kawasan perdagangan di Jalan Ahmad Yani dan sekitarnya } \\
\text { Kesawan Square). }\end{array}$ \\
\hline Kawasan III & Gedung AVROS, Gedung PT. Wahid, Room Katolik. \\
\hline Kawasan IV & Istana Maimoon, Mesjid Raya Al Mansun, Taman Sri Deli. \\
\hline Kawasan V & $\begin{array}{l}\text { Kawasan sekitar Jalan Jenderal Sudirman, Jalan Letjen Suprapto, } \\
\text { Jalan Ir. H Juanda. }\end{array}$ \\
\hline Kawasan VI & Kawasan Jalan Diponegoro, Jalan Imam Bonjol, dan sekitarnya. \\
\hline Kawasan VII & $\begin{array}{l}\text { Kawasan Jalan Kapten Maulana Lubis dan sekitarnya, Jalan } \\
\text { Pengadilan, Jalan Listrik, dan Jalan S. Parman. }\end{array}$ \\
\hline Kawasan VIII & Kawasan Jalan Prof. Moh. Yamin dan Jalan Sena. \\
\hline
\end{tabular}

Sumber: Diolah dari Laporan Akhir Rencana dan Strategi Revitalisasi Kawasan dan Bangunan Bersejarah Kota Medan oleh Dinas Tata Kota dan Tata Bangunan Kota Medan Tahun 2003.

Kenyataan adanya begitu banyak bangunan bersejarah menunjukkan kerelevanan Kota Medan dijadikan sebuah kota kawasan wisata berbasis bangunan bersejarah sekaligus dalam rangka melestarikan warisan budaya bernilai sejarah dan estetika tinggi, terutama dengan 
mengedepankan city tour (tur keliling kota) berupa kunjungan di setiap gedung kuno yang masih tersisa. Sebagai kota wisata, Kota Medan tidak saja memiliki kekayaan bangunan bersejarah yang kaya dengan arsitektur yang mewakili prestasi khusus dalam suatu gaya tertentu, tetapi juga beberapa objek dan daya tarik wisata menarik lainnya seperti Taman Buaya, Taman Margasatwa, Taman Ria, Taman Ahmad Yani, Danau Siombak Indah, Perumahan Nelayan Indah, Rahmad Gallery, Pusat Industri Kecil Menteng, dan sebagainya.

\section{ESTETIKA BANGUNAN BERSEJARAH}

Estetika memiliki pengertian yang sangat kompleks dan terus berubah-ubah dari masa ke masa sejalan perubahan zaman. Pengertian yang umum digunakan adalah, hasil pencerapan, komunikasi, dan kontak rasa (indah dan seni) yang dapat merangsang serta membangkitkan pengalaman atau kenikmatan yang bersifat kontemplatif dan transendental (Dibia, 2006).

Sementara itu, estetika kota tidak lain adalah estetika tentang (per)kota(an), termasuk yang dibentuk oleh keindahan arsitektural bangunan bersejarahnya. Sementara estetika bangunan bersejarah dari sebuah kota adalah bagian dari kota yang dilestarikan karena mewakili prestasi khusus dalam suatu gaya tertentu. Tolok ukurnya dikaitkan dengan nilai estetis dan arsitektonis/arsitektural yang tinggi dalam bentuk antara lain struktur, tata ruang, dan ornamennya.

Dalam kaitannya dengan bangunan bersejarah di Kota Medan, secara konseptual, harus dibedakan antara art by destination dan art by metamorphosis sebagaimana yang dilakukan oleh Maquet (1986). Secara umum, Kota Medan dari segi estetikanya pada masa kini adalah art by metamorphosis. Jadi, membahas "keindahan wajah" Kota Medan adalah membahas art by metamorphosis karena pada waktu pendiriannya dahulu tentu bukan berkategori "bangunan bersejarah" yang memiliki keindahan arsitektural tetapi bangunan fungsional biasa. Predikat "bersejarah" baru diberikan belakangan ini. Namun, bangunan bersejarah di Kota Medan sebagai dirinya sendiri tetap merupakan art by destination. Istana Maimoon misalnya, sebagai dirinya sendiri, adalah sebuah karya seni. Hal ini karena, bangunan bersejarah sebagai sebuah karya agung yang artistik memang diciptakan dengan maksud dan tujuan untuk dipajangkan dan/atau dinikmati daya pikat artistiknya tersebut. 
Sebelum dilakukan pengkajian secara estetika terhadap bangunan bersejarah di Kota Medan perlu digarisbawahi bahwa penghancuran bangunan bersejarah yang dimaksud meliputi hegemoni dan demolition by neglection serta pengabungannya.

Hegemonisasi adalah proses penghancuran dengan cara menjebak masyarakat agar masuk ke dalam alam pikiran pemerintah (dan pengusaha pemilik bangunan bersejarah), sehingga seolah-olah penghancuran sah dan masuk akal dilakukan. Dengan kata lain, masyarakat setuju dengan penghancuran yang dilakukan. Hegemonisasi diambil dari konsep hegemoni Antonio Gramsci dalam bukunya Selections from Prison's Notebook (1971).

Tidak mudah menerjemahkan demolition by neglection tetapi, sudah pasti, bahwa yang dimaksud adalah penghancuran secara segaja dengan membiarkan sebuah gedung rusak dengan sendirinya. Dengan rusaknya gedung, otomatis tampak bahwa pembongkaran sah untuk dilakukan. Istilah demolition by neglection pertama kali diungapkan oleh Hasti Teraket dari BWS yang memimpin perlawanan terhadap penghancuran bangunan bersejarah di Kota Medan (wawancara dengan penulis pada awal 2006).

Penghancuran bangunan bersejarah secara koersif berarti bahwa tindakan tersebut dilakukan dengan unsur paksaan, bila perlu dengan tekanan dan kekerasan, serta sering melibatkan aparat militer. Penghancuran dengan cara koersif adalah lawan dari cara-cara hegemonik karena hegemoni adalah kekuasaan yang halus, canggih, dan intelektual.

\section{Bangunan Bersejarah yang Dihancurkan}

Dengan banyaknya jumlah bangunan bersejarah di wilayah Kota Medan dan, di sisi lain, relatif kecilnya ruang dalam tulisan tugas ini, beberapa yang berikut ini dipilih (mewakili) untuk menjelaskan estetikasi bangunan-bangunan tersebut. Bangunan-bangunan tersebut adalah Mega Eltra, Istana Maimoon, dan Eks Bank Modern.

\section{(1) Mega Eltra}

Mega Eltra merupakan Kantor Dagang Perusahaan Belanda Lindeteves-Stokvis dan Bataafse Petroleum Maatschappij sebagai pusat perdagangan barang-barang yang terbuat dari metal untuk kebutuhan berbagai perusahaan perkebunan di Sumatera Utara (suarakarya.online.com-/news.html/?id: 40734). Dahulunya gedung ini merupakan sebuah gedung terkenal tempat penyimpanan tembakau yang berdiri pada tahun 1912 ini memiliki 
tingkat keindahan yang tinggi. Secara estetik, bangunan Mega Eltra tergolong unik sebab dibangun dengan memadukan arsitektur Eropa dan tropis yang sangat dipengaruhi oleh gaya Art Deco tahun 1930-an. Mega Eltra pun memiliki nilai historis yang sangat tinggi dan menunjukkan kejayaan Kota Medan masa lalu sebagai kota perdagangan internasional.

Dari bentuknya, gedung ini menggunakan dormer (jendela di atap bangunan) yang sangat indah, yang tidak bisa dijumpai pada bangunan manapun saat ini. Jendelanya memiliki bukaan-bukaan yang mencolok ke dalam, sehingga didapati double facade yang merupakan antisipasi terhadap terik matahari ke dalam bangunan (Hal ini mengingat Kota Medan tergolong panas). Facade-nya diartikulasikan dengan kehadiran pengulangan arcade terhadap orientasi facade yang linear. Dindingnya berbentuk gable, yaitu segitiga di ujung atap, yang menyerupai bentuk arsitektur rumah-rumah di Belanda, yang secara keseluruhan menjadi focal point bangunan. Bagian bawah bangunan merupakan adaptasi dari arsitektur tradisional (rumah panggung).

Mega Eltra dibongkar pada tahun 2000 dan kemudian di areal ini dibangun supermarket Palm Plaza. Supermarket sendiri, secara semiotika budaya, menunjukkan cara hidup manusia kontemporer di samping menunjukkan bahwa si pemilik sekadar homo ekonomikus dan bukan homo kultur mengingat Kota Medan berbasiskan bangunan bersejarah. Dengan penghancuran tersebut, fungsi Mega Eltra berubah pada masa kini, menjadi sebuah bangunan ekonomi. Maknanya pun tidak sama dengan dahulu ketika Mega Eltra adalah sebuah bangunan bersejarah yang menandai keagungan Kota Medan sebagai sebuah kota tua yang menjaga (melestarikan) kebudayaan dan peradaban kotanya.

Dapat dicatat bahwa, dalam sejarah penghancuran bangunan bersejarah di Kota Medan, salah satu yang terbesar adalah kasus Mega Eltra itu sendiri. Penghancurannya sudah dimulai sejak 15 Mei 2002 setelah pihak Mega Eltra (saat itu merupakan sebuah perusahaan penyaluran semen) menjualnya kepada Suwandi Wijaya dan Edy Johan alias Lim Lie Tju dengan harga Rp. 26 milyar. Penghancuran dilakukan karena pemilik baru akan merombaknya menjadi sebuah pusat perbelanjaan modern.

Sebenarnya bangunan Mega Eltra mempunyai persyaratan untuk dimasukkan ke dalam daftar bangunan bersejarah yang dilindungi sesuai Undang-undang Republik Indonesia Nomor 5 Tahun 1992 tentang Benda Cagar Budaya dan juga Perda Nomor 6 Tahun 1988 tentang Perlindungan Bangunan dan Lingkungan yang Bernilai Sejarah di Kota Medan. Namun, sangat 
disayangkan, Mega Eltra justru tidak termasuk dalam salah satu dari 42 bangunan bersejarah yang dilindungi. Akibatnya adalah, bangunan yang berada di inti Kota Medan ini berhasil dirubuhkan meskipun pemilik baru belum memiliki Izin Mendirikan Bangunan (IMB) dari Pemkot Medan.

Bangunan Mega Eltra yang merupakan peninggalan Belanda tetap saja dihancurkan dengan menelan biaya sekitar Rp 400 juta dengan bantuan prajurit Batalyon Zipur 1, Kodam 1 Bukit Barisan (detik.com, 25 Oktober 2004) dan, setelah itu, muncullah sebuah supermarket Palm Plaza padahal nilai estetika, keunikan, dan kesejarahan gedung sebelumnya sama sekali tak tertandingi. Nilai estetikanya tidak dapat dijumpai lagi pada bangunan manapun sekarang.

\section{(2) Istana Maimoon}

Istana Maimoon sebagai gedung istana kediaman resmi Sultan Deli didirikan pada tahun 1888 di mana, sebelumnya Sultan Deli tinggal di Istana Kampong Bahari di Labuhan. Pembangunan kawasan Istana Maimoon dimungkinkan oleh pendapatan Sultan Deli yang sangat besar dari pembayaran pemberian tanah untuk konsesi perkebunan yang dibuka serta hasil tahunan sewa tanah (cijns). Hasil panen tembakau pada tahun 1888 yang mencapai sekitar 125.000 pak membuat Tanah Deli menjadi salah satu produsen tembakau terbesar di dunia dan Amsterdam menjadi pasar tembakau terbesar di dunia pula (Sinar, 2001).

Istana Maimoon bergaya arsitektur perpaduan di antara gaya-gaya Melayu tradisional, Islam (Timur Tengah/India), dan Eropa. Dikatakan Melayu tradisional, karena gedung ini memanjang ke depan dan bertingkat dua. Atapnya berbentuk limas. Teras di kiri dan kanan berupa anjungan. Pinggiran atapnya berukir Pagar Tringgalum. Pinggiran atas lislplank-nya berukir Awan Boyan.

Dikatakan Islam (Timur Tengah/India) karena ground plan bangunannya terdiri atas tiga bagian. Dalam pengaruh ini terdapat pada bagian tengah bangunan yang bersegi empat dan biasanya merupakan ruangan terbuka pada mesjid-mesjid kuno di Timur Tengah dan India yang disebut sahn. Pada sisinya terdapat ganag beratap tempat berteduh yang disebut mugatha atau suntuh. Pengaruh Islam Timur Tengah sangat kental terdapat pada lengkungan-lengkungan (arcade) bangunan, baik yang berbentuk lunas perahu terbalik --dikenal sebagai lengkungan Persia-- maupun lengkungan yang berbentuk ladam kuda atau lengkungan asli pada gang-gang 
beratap di sekitar istana, tiang kayu penyangga atap istana, dan tiang penyangga kubah mesjid. Pengaruh lainnya terdapat pada atap kubah istana yang dihiasi bulan sabit.

Dikatakan Eropa karena gedung ini memiliki jendela dan pintu bergaya Eropa. Bangunan bersejarah yang paling populer --objek wisata primadona Kota Medan-- adalah Istana Maimoon.

\section{(3) Eks Bank Modern}

Eks Bank Modern yang berdiri pada tahun 1929 pada saat ini telah mengalami perubahan bentuk dari dua lantai menjadi ruko lima lantai. Arsitekturnya bergaya Eropa (Art Deco dan lokal).

Gedung ini dahulu adalah kantor perwakilan Stork, yaitu sebuah perusahaan Belanda yang memproduksi dan menjual mesin dan industri pengolahan hasil perkebunan di Sumatera. Yang diubah adalah bentuk depan dan samping bangunan di mana sebelumnya kaya dengan detail ornamen paduan elemen disain Eropa dan arsitektur lokal (Melayu). Sesungguhnya, kekuatan estetis Eks Bank Modern terletak pada jendela-jendela depan dan pada sisi-sisi bangunan, yaitu gaya art deco. Jendela-jendela tersebut sebagian besar telah ditutup dengan batu bata karena terjadi alih fungsi bangunan.

Bangunan ini seharusnya dipertahankan karena memiliki posisi yang sangat penting dalam sejarah perkembangan industri perkebunan di Sumatera Utara dan bagi kebutuhan karakter kawasan bersejarah Kesawan secara keseluruhan. Jadi secara fungsional, bangunan bersejarah ini kehilangan fungsinya sebagai bangunan bersejarah yang berarti pemaknaannya pun berubah.

\section{Kritik atas Penghancuran Bangunan Bersejarah}

Sudah pasti bahwa Kota Medan akan mengalami kerugian yang tak ternilai harganya karena banyak bangunan bersejarahnya yang ditelantarkan, termasuk gagalnya upaya pelestarian budaya dan pengembangan pariwisata. Selain tiga bangunan bersejarah seperti yang telah dibahas, di Jalan Diponegoro, misalnya, tidak kurang dari delapan bangunan lama kini kondisinya sangat memprihatinkan, termasuk empat vila kembar yang diapit oleh Bank Kesawan dan Rumah Sakit Malahayati. Bangunan di sepanjang jalan ini adalah contoh vila perkebunan yang dibangun oleh Deli Maaschappij, sebuah perusahaan perkebunan terbesar di Pantai Timur 
Sumatera Utara. Vila-vila tersebut mengadopsi gaya hidup Eropa yang dipadukan dengan sentuhan budaya lokal berupa dekorasi Melayu dan adaptasi rumah tropikal. Di tengah serbuan bangunan baru yang hampir tanpa karakter, keberadaan vila-vila tersebut menjadi semacam saksi sejarah yang penting tentang kelahiran Kota Medan.

Di Jalan Ahmad Yani, yang dikenal sebagai daerah Kesawan, terdapat rumah besar Tjong A Fie, seorang saudagar besar Tionghoa pada masa penjajahan Belanda. Di depan rumah ini, dapat ditemui beberapa bangunan besar yang sedang kosong, tidak terawat, dan berdebu. Ada juga sejumlah bangunan berarsitektur unik yang telah kehilangan daya pikatnya karena tampak kusam dan rapuh. Yang lebih buruk lagi, kawasan Jalan Ahmad Yani terancam menjadi kawasan budidaya sarang burung walet. Dalam beberapa tahun terakhir ini, beberapa bangunan baru berdiri menjulang tanpa disesuaikan dengan bangunan lain di sekitarnya. Ironisnya, yang menjadi bangunan sarang burung walet di Kesawan adalah kawasan inti kota yang dilindungi oleh Perda No. 6 Tahun 1988 dan dalam kenyataannya sama sekali tidak ada perlindungan dan upaya pemeliharaan dari Pemkot Medan.

Tindakan penelantaran (dengan sengaja) dilakukan untuk menunjukkan kepada publik bahwa seolah-olah bangunan bersejarah tidak produktif dan layak dihancurkan (dan kemudian diganti dengan yang lebih produktif dan bisa memberi kontribusi). Di sinilah hegemoni dijalankan melalui wacana-wacana yang sangat kental bermuatan kekuasaan. Dalam pemikiran Gramsci (1971), hegemoni mencakup sarana kultural dan ideologis yang di dalamnya kelompokkelompok penguasa atau pihak-pihak yang dominan menjalankan dan melestarikan kekuasaannya dalam masyarakat melalui konsensus (persetujuan) terhadap kelompok-kelompok yang dikuasai atau pihak-pihak yang didominasi.

Penelantaran bangunan bersejarah bernilai tinggi yang seolah-olah tidak berfungsi mendapat persetujuan masyarakat karena dengan dibangun sebuah tempat bisnis (supermarket, mall, plaza, dan sejenisnya) di atas bangunan lama, akan bermanfaat memberikan kesejahteraan bagi masyarakat. Masyarakat pun, dalam pikiran awam mereka, menerima dan menganggap pendirian supermarket atau yang lainnya merupakan kebutuhan mereka. Ini berarti formasi diskursif yang dikembangkan oleh pemerintah (Kota Medan) dalam kolaborasinya dengan pengusaha besar berhasil menjebak masyarakat ke dalam satu wacana utama untuk mendukung pembongkaran bangunan bersejarah yang dilakukan. Formasi diskursif adalah terma penting yang dikembangkan oleh Foucault (2002) dalam uraiannya mengenai hubungan tak terpisahkan 
antara pengetahuan/kebenaran dan kekuasaan. Formasi diskursif adalah sebuah kerangka kerja konseptual yang memungkinkan diterimanya beberapa mode pemikiran dan ditolaknya beberapa mode pemikiran lainnya.

\section{SIMPULAN}

Bangunan bersejarah di Kota Medan satu per satu dihancurkan dan digantikan oleh bangunan-bangunan modern. Ini berarti kota ini akan kehilangan estetikanya sendiri yang justru merupakan bukti sejarah kebudayaan dan peradaban sejak awal berdirinya. Dalam hal ini, Pemerintah Kota Medan justru mengingkari peraturannya sendiri yang seharusnya dijaganya dengan memilih berkolaborasi dengan kapitalisme (pengusaha) dibandingkan menjaga keseimbangan hubungan sinergis dengan masyarakat dan pengusaha.

Kontradiksi penghancuran bangunan bersejarah terjadi karena, dalam kenyataannya, di Kota Medan sedang digalakkan upaya industrialisasi pariwisata yang berkenaan dengan pemanfaatan aneka bangunan tua bersejarah sebagai objek dan daya tarik wisata utama, yang sebenarnya potensial menyejahterakan masyarakat dan menjaga pelestarian warisan budaya itu sendiri. Padahal, di luar Mega Eltra, Istana Maimoon, dan Eks Bank Modern, masih sangat banyak bangunan bersejarah peninggalan Belanda, yang terbengkalai dan tak terawat di luar daftar bangunan yang dilindungi Perda No. 6 Tahun 1988 (suarakarya.online.com/news. html/?id:40734).

Sebagai saran, dapat dikemukakan bahwa penghancuran bangunan bersejarah di Kota Medan dapat dijadikan refleksi untuk melangkah ke depan dengan penyadaran bahwa penghancuran seperti itu hanyalah akan menghilangkan estetika kota dan bahkan menghilangkan sejarah kota, yang sekaligus menghilangkan identitas dan kebanggaan warga setempat terhadap kotanya sendiri.

Perda No. 6 Tahun 1988 yang sudah ada hendaknya tidak dijadikan "macan kertas" di mana di dalamnya terdapat penegakan hokum yang konsisten dan pemerintah sudah seharusnya berada terdepan dalam penegakannya, lebih-lebih Orde Baru sudah berlalu dan saat ini eranya reformasi. Bila perlu, bangunan-bangunan bersejarah lainnya yang belum dilindungi segera dimasukkan dalam Perda tersebut. 
Masyarakat sebaiknya berada di belakang kelompok kritis dan intelektual yang membela pemberhentian penghancuran bangunan bersejarah. Kalau tidak, penghancuran akan dengan lebih mudah terjadi.

\section{DAFTAR PUSTAKA}

Barrett, Terry. 2004. Critizing Art, Understanding the Contemporary (second edition). Mountain View, California: Mayfield Publishing Company.

Blocker, Gene H. and Jennifer M. Jeffers. 2000. Contextualizing Aesthetics: From Plato to Lyotard. Belmont, CA.: Wadsworth Publishing Company.

detik.com, "Gedung Tua di Medan, Identitas yang Mulai Hancur”, Selasa 25 Oktober 2004.

detik.com, “Gedung Tua di Medan, Perda, dan Penyalahgunaan Izin”, Selasa 26 Oktober 2004.

Dibia, I Wayan. 2006. "Bahan Kuliah Estetika Program S3 Kajian Budaya Universitas Udayana”. Denpasar: -

Foucault, Michael. 2002. Pengetahuan dan Metode, Karya-karya Penting Foucault (suntingan, terjemahan Aesthetics, Method, and Epistemology, Essential Works of Foucault 19541984). Yogyakarta: Jalasutra.

Gramsci, Antonio. 1971. Selections from Prison Notebooks. New York: International Publisher.

Kompas, "Berlanjut, Pembongkaran Bangunan Bersejarah”, Rabu 27 Oktober 2004.

Maquet, Jacques. 1986. The Aesthetic Experience, An Anthropologist Looks at the Visual Arts. Yale: Yale University Press.

Sinar, Tengku Luckman. 2001. Sejarah Medan Tempo Doeloe. Medan: Perwira.

suarakarya.online.com/news.html/?id:40734 "Pemda Sumut Membiarkan Bangunan Bersejarah Dihancurkan Pengusaha".

\section{Riwayat Hidup Singkat}

Dra. Asmyta Surbakti, M.Si adalah dosen Fakultas Sastra Universitas Sumatera Utara (USU) Medan. Ia merupakan lulusan Program Magister Kajian Budaya Universitas Udayana pada tahun 2004 dan menempuh studi di Program Doktor Kajian Budaya Universitas Udayana sejak tahun 2005. Ia adalah juga seorang pegiat di Badan Warisan 
Sumatera (BWS) Medan, berkenaan dengan pelestarian benda-benda warisan/pusaka budaya, khususnya bangunan bersejarah. 